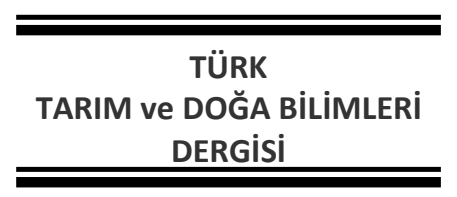

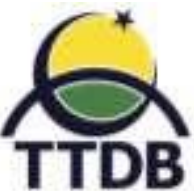

www.dergipark.gov.tr/turkjans

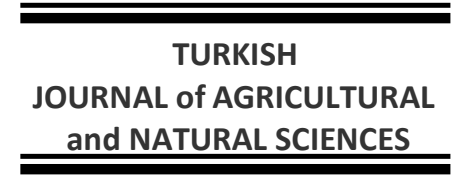

Research Article

\title{
Effect of PEG Induced Drought Stress on Germination and Seedling Traits of Maize (Zea mays L.) Lines
}

\author{
Manu M. Magar ${ }^{1 *}$, Atit Parajuli ${ }^{1}$, Bindeshwor P. Sah ${ }^{1}$, Jiban Shrestha ${ }^{2}$, Binesh M. Sakh ${ }^{1}$, Keshab B. Koirala ${ }^{3}$, \\ Shambhu P. Dhital ${ }^{1}$ \\ ${ }^{1}$ Nepal Agricultural Research Council, Nepal \\ ${ }^{2}$ National Commercial Crop Research Program, Pakhribas, Dhankuta, Nepal \\ ${ }^{3}$ National Maize Research Program, Rampur Chitwan, Nepal \\ *Corresponding author: manu.bdnarc@gmail.com
}

\begin{abstract}
Received: 11.06 .2018
Received in Revised: 24.02.2019

Accepted: 25.02 .2019

Abstract

Maize is the staple food crop in hilly areas of Nepal. Drought stress is one of the most important crop growth limiting factors leading to lower crop productivity in these areas. Maize seedlings are susceptible to drought stress. Nine lines (Arun-2, NML-1, Rampur Composite, RL-100, RL-105, RI-106, RL-197, RML-18 and RML-8) of maize obtained from National Maize Research Program, Rampur, Chitwan, Nepal to study their tolerance to drought stress. An experiment was designed to study their drought tolerance by subjecting to four levels of osmotic potential (0, -5, -10 and -15 bar) induced by polyethylene glycol (PEG) 6000 in two factor completely randomized design with three replication at Biotechnology Division, National Agricultural Research Institute, Khumaltar, Lalitpur, Nepal. Effects of different levels of PEG 6000 were found significant on all traits studied viz. Germination rate (\%), Speed of germination, Root length, Shoot length, Root Shoot ratio, Seedling length, Seedling fresh weight, Seedling dry weight and Vigor index. Line Arun-2 was recorded as best performer followed by Rampur Composite and RL-105 for all the traits analyzed. Lines RL-100, RL-106, RL-197, RML-18 and RML-8 showed poor performance under the same levels of PEG induced drought stress. Furthermore, the results also showed that maize manifests better genetic expression such as drought tolerance under severe moisture stress conditions in soil. Therefore, Lines Arun-2, Rampur Composite and RL105 are suggested for varietal improvement program for drought stress conditions.
\end{abstract}

Keywords: Drought stress, maize, osmotic potential, PEG, seedling parameters.

\section{Introduction}

Maize (Zea mays L.) is the major cereal crop of the world with the largest area of 185 million ha and productivity of $5.62 \mathrm{t} / \mathrm{ha}$ (FAOSTAT, 2017). It is second staple food and the principal feed, fodder, fuel crop and source of energy in hills of Nepal. The trend of maize production is decreasing by $4.6 \%$ in $2012 / 13$, while the population to be fed is increasing to $27,53,9000$ in the same year by $1.3 \%$ as compared to $2011 / 13$ in our country (MOAD, 2013). Inspite of its high demand, production is limited due to various biotic as well as abiotic stresses. Among various abiotic factors limiting maize production, drought stress has been realized as most devastating environmental stress worldwide affecting large part of agricultural land (Avramova et al., 2015; Huang et al., 2015; Langridge and Reynolds, 2015; Obidiegwu et al., 2015; Zhan et al., 2015). The loss in maize production is accounted approximately $16 \%$ in lowland tropics (Edmeades et al., 2006) and it reached up to 60\% in severely drought-affected regions/seasons (Ribaut et al., 2009). The current trends of climatic changes will increase water scarcity and will reduce maize productivity by $15-30 \%$ (Lobell et al., 2014).

The Damaging effect of drought was more severe when it coincided with germination, seedling development and flowering stages (Khayatnezhad et al., 2010 and Tsago et al., 2014). It shows that crop sensitivity to water stress at early growth stage plays important role in overall success of a crop. Therefore, biometric attributes 
at the early growth stages can be used as selection criteria for improving crop resistance against drought (Blum, 2011; Comas et al., 2013). It can be supported by the evidence that several germination and seedling growth indices are frequently used as predictors to screen crops for drought tolerance (Comas et al., 2013; Ayalew et al., 2014; Shamim et al., 2014; Obidiegwu et al., 2015, Khan et al., 2016; Álvarez-Iglesias et al., 2017, Queiroz et al., 2019).

Polyethylene glycol (PEG) is metabolically inactive compound frequently used to induce uniform drought stress at early germination and seedling growth stages to study the effects of water stress in different groups of plants (Kauser et al., 2006,Khodarahmpour, 2011 and Shamim et al., 2014). The major part of maize growing area in Nepal is located in the Mid-hills under rainfed condition. Stable yield of maize variety under rainfed condition requires it to have drought resilient traits. For the development of elite hybrids having drought tolerance, the existence of heritable drought tolerant trait in the parental

inbreeds is a must for the maize breeders. The major aim of present study was to compare the maize inbred lines developed by the National Maize Research Program, Rampur; Chitwan, Nepal under PEG induced drought stress for emergence and early seedling traits.

\section{Materials and Methods}

\section{Plant materials and experimental design}

Nine maize inbred lines (Arun-2, NML-1, Rampur Composite, RL-100, RL-105, RI-106, RL197, RML-18 and RML-8) collected from National Maize Research Program (NMRP), Rampur Chitwan were used to study the effect of drought stress by using PEG-6000 on germination and early seedling growth characters. The experiment was performed as two factorial completely randomized designs with three replications at Biotechnology Division, Khumaltar, Lalitpur.

\section{Surface sterilization and osmolyte}

The collected seeds were selected for size homogeneity, boldness and surface sterilized with $1 \%(v / v)$ sodium hypochlorite for 5 minutes and then rinsed twice with distilled water. The ten surface sterilized seeds of each line were placed between paper with four different concentration (0, $-5,-10,-15$ bars) of PEG-6000 solutions and kept in germinator at $25+/-2^{\circ} \mathrm{C}(80+/-5 \%$ relative humidity). The osmotic potential of PEG-6000 was calculated according to Micheal and Kaufmann (1973).

\section{Measurement times and statistical analysis}

The respective PEG solution was replaced to every treatment on daily basis and number of seeds germinated was recorded everyday up to 7 days. The seeds were considered germinated when the emerging radicals and plumules were nearly $2 \mathrm{~mm}$ long. After seven days, germination percentage and seedling vigor index was measured by International Seed Testing Association standard (ISTA, 1996). At the end of $7^{\text {th }}$ day other seedling parameter i.e. the germination percent (Formula 1 ), Speed of germination (Formula 2), root length, shoot length, seedling length, root/shoot length ratio and seed vigor index (Formula 3) were also measured.

Formula 1: Scott et. al. (1984)

Germination Percent $=$ (number of germinated seeds/ number of experimental seeds) $\mathrm{x} 100$

Formula 2: Agrawal, R.L. (2013)

$$
F G=\frac{1}{1}+\frac{2}{2}+\frac{3}{3}+\frac{4}{4}+\frac{5}{5}+\frac{6}{6}+\frac{7}{7}
$$

Where, SFG: is speed of germination; N: the number of germinated seeds on that day and D: Number for the day of observation.

\section{Formula 3:}

Seed Vigor Index = Germination Percent $x$ Seedling Length

The data collected were subjected to analysis of variance technique (Steel et al., 1997) using $\mathrm{R}$ studio version 1.1 .453 and also mean comparison between maize lines and various levels of PEG was performed by $R$ studio version 1.1.453. The principle component analysis and correlation matrix was performed by Minitab version 18.1.

\section{Results and Discussions}

Moisture stress at critical growth stages of cereals like germination, seedling establishment, tillering and reproductive stage may result from yield reduction to lethality for crops (Farooq et al, 2011). In the present study, seedling stage drought tolerant traits are studied to identify the tolerant maize lines from nine NMRP inbred lines included in the experiment.

\section{Germination percent (GP) and speed of germination (SFG)}

The results obtained from the study of seedling traits of NMRP maize inbred lines 
subjected over different concentration of PEG6000 such as -5 bars, -10 bars and -15 bars were found to have significant effect $(P \leq 0.001)$ on the germination traits of the maize genotypes. Analysis of variance and mean comparison showed that there were significant differences between treatment, genotype and genotype by treatment interaction (Table 1). The result of decrease in the germination percent with increasing the stress level were similar with the results of ÁlvarezIglesias et al., (2018), Partheban et al (2017), Khayatnezhad et al., (2010), Khodorahmpour (2011) and Mostafavi et al. (2011). Ahmad et al., (2009) found that drought stress prevented seed germination in sunflower which is in agreement with the current result in which seed germination of all genotypes at lowest osmotic potential of -15 bars; except one line (Arun-2) is completely inhibited.

Mean comparison (Table 3 ) between lines showed that Germination percent (GP) was highly significant for lines in control ( 0 bars) as well as under different levels of PEG. Maize lines NML-1 (100\%), Rampur Composite (100\%) and RL-105 (100\%) had highest GP with Arun-2 (90\%) at par with the lines above. With decreasing osmotic potential from 0 to -15 bars, significant reduction in GP was observed. Maize line Arun-2 with $10 \%$ GP at the osmotic potential of -15 bars showed tolerance towards artificially induced water stress. The mean GP for different treatments were 65.56 $\%$ (0 bars), 46.67\% (-5 bars), $14.07 \%(-10$ bars) and $1.11 \%$ (-15 bars). Maize lines Arun-2, Rampur Composite and RL-105 were high performer in decreasing osmotic potential with Arun-2 (10\%) showing promise at the lowest osmotic potential of -15 bars. This is supported by the results of Tripathi (2012) in which Arun-2 performed well with higher number of cobs per plant and highest grain yield under natural water stress condition.

Similar to GP, lines Arun-2, Rampur Composite and RL-105 performed better with higher value of speed of germination (SFG) along different osmotic potential of PEG. The average SFG decreased from 2.41 (0 bars), 1.235(-5 bars), 0.304 (-10 bars) to 0.022 (-15 bars). In the present study, moisture stress reduced rate of germination by (99\%). Although the reduction in SFG was imminent with decreased osmotic potential of PEG, lines Arun-2, Rampur Composite and RL-105 consistently out-performed other inbred lines in their respective levels of PEG. This result is in agreement with other experiments in tomato (Kumar et al., 2017), in safflower (Mostafavi, 2011) and oat (Mut et al., 2010).

\section{Root length, shoot length, seedling length and root to shoot ratio}

The root is the vital organ in plants which encounters water stress at first and those genotypes with better root development under stress are likely to be drought tolerant (Kulkarni and Deshpande, 2007). In the current study, significant differences were found among maize lines for root length (RL), shoot length $(S L)$ and seedling length (SDL) for various levels of PEG. There was reduction in RL (92.40\%), SL (97.19\%) and SDL (95\%) from 0 bars to -10 bars of osmotic potential of PEG which is in agreement with the results of Petcu et. al., 2018 and Khayatnezhad et al., (2010). With $1 \mathrm{~cm} \mathrm{RL}$ and SL at -15 bars, Arun2 was the most tolerant line to severe exposure to artificially induced moisture stress condition as the drought resistance is characterized by an extensive root growth and small reduction of shoot growth in drought stressed condition (Guoxiong et al., 2002). The present study also identifies -10 bars and -15 bars as the most effective PEG levels of reducing $\mathrm{RL}$, SL and SDL (Table 4, Fig. 2).

The root to shoot ratio showed increasing trend by reducing the osmotic potential from 0 bars to -15 bars. The increasing trend was distinct for lines Arun-2 and RL-105 (Fig. 2). Similar result was reported by Queiroz et al., (2019) in maize and sorghum. Increasing trend of root shoot ratio indicates that the drought tolerance mechanism adapted in the genotype as the increased ratio helps plant to cope with transpiration effect during drought and against lodging at maturity.

\section{Seedling fresh and dry weight}

Maize lines Arun-2 had the highest Seedling fresh weight (SFW) and Seedling dry weight (SDW) and the decreasing osmotic potential had increasing trend of the trait (Fig. 2). Similar results were found in the experiments of Hanan (2007), Singh and Usha (2003) and Shatpathy et al. (2018). With the SFW value of $0.437 \mathrm{gm}$ and SDW value $0.35 \mathrm{gm}$. at osmotic potential of -15 bars, Line Arun- 2 was the best performer among all lines. 


\section{Vigor index}

Seed vigor index can better reflect the drought resistance and germination characteristics when subjected over drought stress condition. Dhanda et al., (2004) indicated that seed vigor index is most sensitive to drought which can be seen in the current study as the vigor index decreased by $99 \%$ upon exposure of lines to lowest osmotic potential of -15 bars. Arun-2 was the least drought prone inbred line with high vigor index at lowest osmotic potential of -15 bars among all the experimental lines. The lines were significantly different over various levels of PEG. Lines Arun-2, Rampur Composite and RL-105 performed best upon decreasing the osmotic potential to -10 bars. The ultimate performer was Arun-2 with higher vigor index value at control $(0$ bars) as well as various levels of osmotic potential of PEG. This is supported by reports of Spielmeyer et al. (2007) in wheat where highly vigorous seeds covered the soil surface quickly reducing the loss of water from the soil, emphasizing the early seedling establishment as major character to sustain drought stress.

\section{Multivariate analysis}

Multivariate scoring was carried out by Principle Component Analysis (Fig. 1) using averaged of replicated values of $\mathrm{GP}, \mathrm{SFG}, \mathrm{RL}, \mathrm{SL}$, Root shoot ratio, SDL, SFW, SDW, VI. One of the most frequently used multivariate method of analysis is Principle Component Analysis (PCA) which reduces the large number of variables to $a$ smaller number of components or factors that captures most of the variance in the observed variables. The nine maize lines represent two distinct groups with different response to various levels of PEG. Similar result was obtained by Partheeban et. al., (2017) when PCA was done for seedling traits of four maize hybrids. The differential response to drought stress could be further tested in the field for drought tolerance characters.

\section{Conclusion}

The result of the present research clearly identifies line Arun-2 as a drought tolerant line followed by Rampur Composite and RL-105 based on Principle Component Analysis. It also outlines germination percent, root length and vigor index as major traits to identify drought tolerance character in the variety during germination and seedling establishment stage. In addition, the current study shows that lowest osmotic potential of PEG for maize seedlings to flourish was -10 bars as seedling germination for all but one variety (Arun-2) is completely inhibited at PEG levels of 15 bars.

\section{Acknowledgement}

This research was supported by Nepal Agricultural Research Council. 
Table 1. Analysis of variance of measured traits on maize lines under different treatment levels

\begin{tabular}{|c|c|c|c|c|c|c|c|c|c|c|}
\hline SnV & nf & $\begin{array}{c}\text { Germination } \\
\text { Percentage }\end{array}$ & $\begin{array}{c}\text { Speed of } \\
\text { Germination }\end{array}$ & $\begin{array}{l}\text { Root Length } \\
(\mathrm{cm})\end{array}$ & $\begin{array}{l}\text { Shoot Length } \\
(\mathrm{cm})\end{array}$ & $\begin{array}{c}\text { Root: Shoot } \\
\text { Ratio }\end{array}$ & $\begin{array}{c}\text { Seedling } \\
\text { Length }(\mathrm{cm})\end{array}$ & $\begin{array}{c}\text { Seedling } \\
\text { Fresh wt.(gm) }\end{array}$ & $\begin{array}{l}\text { Seedling Dry } \\
\text { wt.(gm) }\end{array}$ & Vionr Index \\
\hline Trt & 3 & $23548 * * *$ & $31.575^{* * *}$ & $149.43 * * *$ & $229.32 * * *$ & $8.146^{* * *}$ & $746.2 * * *$ & $132.9 * * *$ & $10.529 * * *$ & $5129165 * * *$ \\
\hline Gen & 8 & $5339 * * *$ & $3.951 * * *$ & $29.28 * * *$ & $10.89 * * *$ & $2.776 * * *$ & $73.8^{* * *}$ & $22.30 * * *$ & $6.087^{* * *}$ & $845426 * * *$ \\
\hline Trt X Gen & 24 & $975^{* * *}$ & $1.005^{* * *}$ & $10.87^{* * *}$ & $6.12 * * *$ & $0.789 * * *$ & $32.0 * * *$ & $7.26 * * *$ & $0.974 * * *$ & $469043^{* * *}$ \\
\hline Error & 72 & 96 & 0.047 & 0.09 & 0.09 & 0.053 & 0.3 & 0.05 & 0.061 & 4903 \\
\hline
\end{tabular}

*** Significant at $\mathrm{P}<0.001, \mathrm{SoV}=$ source of variation, Trt = treatment (different concentrations of PEG), Gen = genotype

Table 2. Effect of drought levels created by PEG 6000 in different maize lines

\begin{tabular}{|c|c|c|c|c|c|c|c|c|c|}
\hline $\begin{array}{l}\text { Drought Level } \\
\text { (bar) }\end{array}$ & $\begin{array}{r}\text { Germination } \\
\text { Percentage }\end{array}$ & $\begin{array}{c}\text { Speed of } \\
\text { Germination (days) }\end{array}$ & $\begin{array}{l}\text { Root } \\
\text { Length } \\
\text { (cm) }\end{array}$ & $\begin{array}{c}\text { Shoot } \\
\text { Length }(\mathrm{cm})\end{array}$ & $\begin{array}{c}\text { Root: Shoot } \\
\text { Ration }\end{array}$ & $\begin{array}{c}\text { Seedling } \\
\text { Length }(\mathrm{cm})\end{array}$ & $\begin{array}{c}\text { Seedling Fresh } \\
\text { Wt. (g) }\end{array}$ & $\begin{array}{l}\text { Seedling Dry } \\
\text { Wt. (g) }\end{array}$ & $\begin{array}{l}\text { Vigor } \\
\text { Index }\end{array}$ \\
\hline 0 bars (control) & $65.56 \mathrm{a}$ & $2.42^{\mathrm{a}}$ & $5.216^{\mathrm{a}}$ & $6.13^{a}$ & $0.743^{b}$ & $11.34^{\mathrm{a}}$ & $4.929^{a}$ & $1.386^{\mathrm{a}}$ & $925.015^{a}$ \\
\hline - 5 bars & $46.67 \mathrm{~b}$ & $1.24^{b}$ & $1.469^{b}$ & $0.87^{b}$ & $1.327^{\mathrm{a}}$ & $2.33^{b}$ & $1.500^{\mathrm{b}}$ & $1.174^{\mathrm{a}}$ & $167.367^{b}$ \\
\hline - 10 bars & $14.074 c$ & $0.30^{c}$ & $0.396^{c}$ & $0.17^{c}$ & $0.526^{c}$ & $0.57^{c}$ & $0.444^{c}$ & $0.465^{b}$ & $28.456^{c}$ \\
\hline - 15 bars & $1.11 d$ & $0.02^{d}$ & $0.111^{\mathrm{c}}$ & $0.00^{c}$ & $0.000^{d}$ & $0.11^{\mathrm{c}}$ & $0.049^{d}$ & $0.039^{c}$ & $0.889^{c}$ \\
\hline
\end{tabular}

Note: Least significant Test (LSD) test was used.

Table 3. Mean comparison of main effects of NMRP maize lines in drought stress levels

\begin{tabular}{|c|c|c|c|c|c|c|c|c|c|}
\hline Treatment & $\begin{array}{c}\text { Germination } \\
\text { Percentage }\end{array}$ & $\begin{array}{c}\text { Speed of } \\
\text { Germination (days) }\end{array}$ & $\begin{array}{c}\text { Root } \\
\text { Length } \\
(\mathrm{cm}) \\
\end{array}$ & $\begin{array}{c}\text { Shoot } \\
\text { Length }(\mathrm{cm})\end{array}$ & $\begin{array}{c}\text { Root: Shoot } \\
\text { Ration }\end{array}$ & $\begin{array}{c}\text { Seedling } \\
\text { Length }(\mathrm{cm})\end{array}$ & $\begin{array}{c}\text { Seedling } \\
\text { Fresh Wt. (g) }\end{array}$ & $\begin{array}{c}\text { Seedling Dry } \\
\text { Wt. (g) }\end{array}$ & $\begin{array}{l}\text { Vigor } \\
\text { Index }\end{array}$ \\
\hline Arun-2 & $55^{\mathrm{ab}}$ & $1.65^{\mathrm{a}}$ & $4.547^{a}$ & $3.165^{a}$ & $1.418^{\mathrm{a}}$ & $7.71^{\mathrm{a}}$ & $4.016^{\mathrm{a}}$ & $1.700^{b}$ & $649.067^{a}$ \\
\hline NML-1 & $47.5^{b}$ & $1.44^{\mathrm{a}}$ & $2.768^{b}$ & $3.086^{\mathrm{a}}$ & $0.581^{b c}$ & $5.85^{b}$ & $2.672^{\mathrm{c}}$ & $0.565^{d}$ & $571.950^{\mathrm{ab}}$ \\
\hline Rampur Composite & $61.67^{\mathrm{a}}$ & $1.62^{\mathrm{a}}$ & $2.914^{b}$ & $2.204^{b}$ & $0.883^{b}$ & $5.12^{\mathrm{b}}$ & $3.105^{b}$ & $2.180^{\mathrm{a}}$ & $495.600^{b}$ \\
\hline RL-100 & $12.5^{c}$ & $0.41^{b}$ & 0.375 & $1.000^{\mathrm{cd}}$ & $0.107^{\mathrm{e}}$ & $1.38^{c}$ & $0.473^{d}$ & $0.265^{d}$ & $38.833^{c}$ \\
\hline RL-105 & $50^{\mathrm{ab}}$ & $1.65^{\mathrm{a}}$ & $3.192^{b}$ & $2.499^{b}$ & $1.383^{a}$ & $5.69^{b}$ & $2.619^{c}$ & $0.964^{c}$ & $507.258^{b}$ \\
\hline RL-106 & $20^{c}$ & $0.56^{b}$ & $0.707^{c}$ & $0.818^{d}$ & $0.218^{\mathrm{de}}$ & $1.52^{c}$ & $0.616^{d}$ & $0.284^{d}$ & $91.492^{c}$ \\
\hline RL-197 & $15^{\mathrm{c}}$ & $0.61^{b}$ & $0.526^{c}$ & $0.958^{\mathrm{cd}}$ & $0.494^{\mathrm{cd}}$ & $1.48^{c}$ & $0.794^{d}$ & $0.368^{d}$ & $52.842^{c}$ \\
\hline RML-18 & $10^{c}$ & $0.38^{b}$ & $0.477^{c}$ & $1.043^{\mathrm{cd}}$ & $0.302^{\text {cde }}$ & $1.52^{c}$ & $0.624^{d}$ & $0.271^{d}$ & $41.808^{c}$ \\
\hline RML-8 & $15^{c}$ & $0.64^{b}$ & $0.676^{c}$ & $1.346^{c}$ & $0.457^{\mathrm{cd}}$ & $2.02^{c}$ & $0.654^{d}$ & $0.297^{d}$ & $75.033^{c}$ \\
\hline
\end{tabular}


Türk Tarım ve Doğa Bilimleri Dergisi 6(2): 196-205, 2019

Table 4. Mean performance of Maize lines under different levels of PEG 6000 for various seedling traits

\begin{tabular}{|c|c|c|c|c|c|c|c|c|c|c|}
\hline Maize Lines & PEG Level & GP & SFG & $\mathbf{R} \mathbf{L}$ & SL & $\mathrm{R}: \mathrm{S}$ ratio & SDL & SFW & SDW & VI \\
\hline Arun-2 & (0 bars) & 90.000 & 3.100 & 12.700 & 10.717 & 1.187 & 23.417 & 8.957 & 2.180 & 2102.130 \\
\hline NML-1 & (0 bars) & 100.000 & 3.467 & 7.633 & 10.160 & 0.750 & 17.793 & 7.283 & 0.410 & 1779.330 \\
\hline Rampur Composite & (0 bars) & 100.000 & 3.233 & 8.403 & 7.243 & 1.160 & 15.647 & 9.887 & 3.297 & 1564.800 \\
\hline RL-100 & (0 bars) & 30.000 & 0.933 & 1.500 & 3.500 & 0.000 & 5.000 & 1.377 & 0.687 & 146.667 \\
\hline RL-105 & (0 bars) & 100.000 & 4.233 & 9.073 & 8.363 & 1.080 & 17.437 & 7.657 & 1.983 & 1743.660 \\
\hline RL-106 & (0 bars) & 60.000 & 1.800 & 2.827 & 3.273 & 0.870 & 6.097 & 2.463 & 1.137 & 365.967 \\
\hline RL-197 & (0 bars) & 40.000 & 1.500 & 1.300 & 3.327 & 0.390 & 4.627 & 2.657 & 1.133 & 186.233 \\
\hline RML-18 & (0 bars) & 30.000 & 1.333 & 1.503 & 3.670 & 0.410 & 5.173 & 2.107 & 0.870 & 158.867 \\
\hline RML-8 & (0 bars) & 40.000 & 2.167 & 2.003 & 4.883 & 0.417 & 6.887 & 1.973 & 0.773 & 277.467 \\
\hline Arun-2 & (- 5 bars) & 90.000 & 2.567 & 3.437 & 1.360 & 2.540 & 4.797 & 4.273 & 2.657 & 433.667 \\
\hline NML-1 & (- 5 bars) & 90.000 & 2.300 & 3.437 & 2.183 & 1.573 & 5.620 & 3.403 & 1.850 & 508.467 \\
\hline Rampur Composite & (- 5 bars) & 90.000 & 2.133 & 2.017 & 1.213 & 1.690 & 3.230 & 1.863 & 3.503 & 291.133 \\
\hline RL-100 & (- 5 bars) & 20.000 & 0.700 & 0.000 & 0.500 & 0.000 & 0.500 & 0.517 & 0.373 & 8.667 \\
\hline RL-105 & (- 5 bars) & 60.000 & 1.467 & 2.420 & 1.030 & 2.347 & 3.450 & 1.890 & 1.220 & 208.200 \\
\hline RL-106 & (- 5 bars) & 20.000 & 0.433 & 0.000 & 0.000 & 0.000 & 0.000 & 0.000 & 0.000 & 0.000 \\
\hline RL-197 & (- 5 bars) & 20.000 & 0.950 & 0.803 & 0.503 & 1.587 & 1.307 & 0.520 & 0.340 & 25.133 \\
\hline RML-18 & (- 5 bars) & 10.000 & 0.170 & 0.403 & 0.503 & 0.797 & 0.907 & 0.390 & 0.213 & 8.367 \\
\hline RML-8 & (- 5 bars) & 20.000 & 0.397 & 0.700 & 0.500 & 1.410 & 1.200 & 0.643 & 0.413 & 22.667 \\
\hline Arun-2 & (- 10 bars) & 30.000 & 0.733 & 1.050 & 0.583 & 1.947 & 1.633 & 2.397 & 1.613 & 52.467 \\
\hline NML-1 & (- 10 bars) & 0.000 & 0.000 & 0.000 & 0.000 & 0.000 & 0.000 & 0.000 & 0.000 & 0.000 \\
\hline Rampur Composite & (- 10 bars) & 56.660 & 1.100 & 1.237 & 0.360 & 0.680 & 1.597 & 0.670 & 1.920 & 126.467 \\
\hline RL-100 & (- 10 bars) & 0.000 & 0.000 & 0.000 & 0.000 & 0.000 & 0.000 & 0.000 & 0.000 & 0.000 \\
\hline RL-105 & (- 10 bars) & 40.000 & 0.900 & 1.273 & 0.603 & 2.103 & 1.877 & 0.930 & 0.653 & 77.167 \\
\hline RL-106 & (- 10 bars) & 0.000 & 0.000 & 0.000 & 0.000 & 0.000 & 0.000 & 0.000 & 0.000 & 0.000 \\
\hline RL-197 & (- 10 bars) & 0.000 & 0.000 & 0.000 & 0.000 & 0.000 & 0.000 & 0.000 & 0.000 & 0.000 \\
\hline RML-18 & (- 10 bars) & 0.000 & 0.000 & 0.000 & 0.000 & 0.000 & 0.000 & 0.000 & 0.000 & 0.000 \\
\hline RML-8 & (- 10 bars) & 0.000 & 0.000 & 0.000 & 0.000 & 0.000 & 0.000 & 0.000 & 0.000 & 0.000 \\
\hline Arun-2 & (- 15 bars) & 10.000 & 0.200 & 1.000 & 0.000 & 0.000 & 1.000 & 0.437 & 0.350 & 8.000 \\
\hline NML-1 & (- 15 bars) & 0.000 & 0.000 & 0.000 & 0.000 & 0.000 & 0.000 & 0.000 & 0.000 & 0.000 \\
\hline Rampur Composite & (- 15 bars) & 0.000 & 0.000 & 0.000 & 0.000 & 0.000 & 0.000 & 0.000 & 0.000 & 0.000 \\
\hline RL-100 & (- 15 bars) & 0.000 & 0.000 & 0.000 & 0.000 & 0.427 & 0.000 & 0.000 & 0.000 & 0.000 \\
\hline RL-105 & (- 15 bars) & 0.000 & 0.000 & 0.000 & 0.000 & 0.000 & 0.000 & 0.000 & 0.000 & 0.000 \\
\hline RL-106 & (- 15 bars) & 0.000 & 0.000 & 0.000 & 0.000 & 0.000 & 0.000 & 0.000 & 0.000 & 0.000 \\
\hline RL-197 & (- 15 bars) & 0.000 & 0.000 & 0.000 & 0.000 & 0.000 & 0.000 & 0.000 & 0.000 & 0.000 \\
\hline RML-18 & (- 15 bars) & 0.000 & 0.000 & 0.000 & 0.000 & 0.000 & 0.000 & 0.000 & 0.000 & 0.000 \\
\hline \multirow[t]{2}{*}{ RML-8 } & (- 15 bars) & 0.000 & 0.000 & 0.000 & 0.000 & 0.000 & 0.000 & 0.000 & 0.000 & 0.000 \\
\hline & Grand me & 31.85 & 0.995 & 1.814 & 1.807 & 0.648 & 3.588 & 1.73 & 0.766 & 280.431 \\
\hline
\end{tabular}




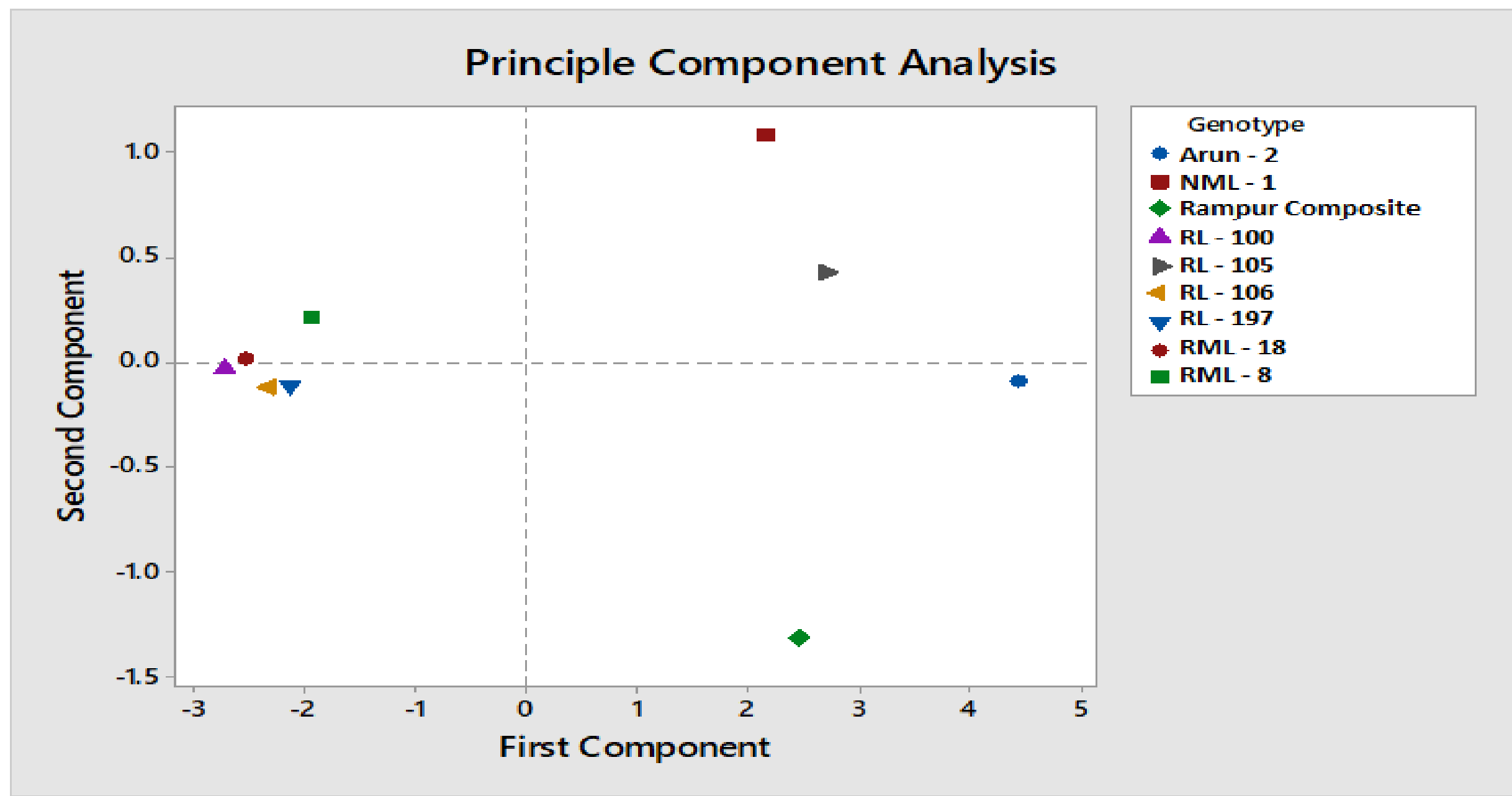

Figure 1. Principle Component Analysis performed on GP, SFG, RL, SL, R:S ratio, SDL, SFW, SDW, VI in nine maize lines in control and different levels of PEG. 


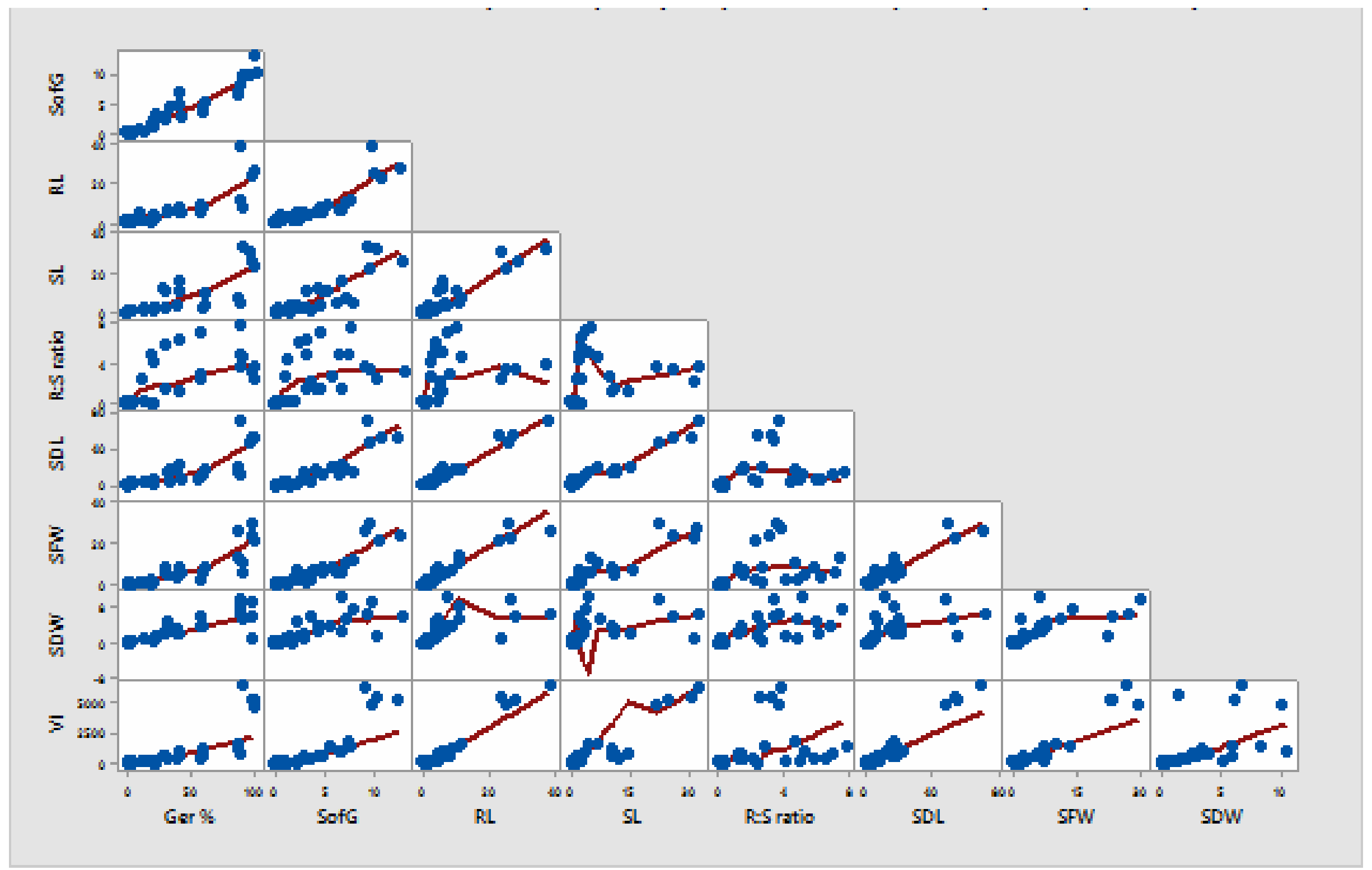

Figure 2. Correlation matrix plot analysis on GP, SFG, RL, SL, R:S ratio, SDL, SFW, SDW, VI in nine NMRP maize lines in control and different levels of PEG. 


\section{References}

Ahmad, S., Ahmad, R., Ashraf, M.Y., Ashraf, M., Waraich, E.A. 2009. Sunflower (Helianthus annuus L.) response to drought stress at germination and growth stages. Pakistan Journal of Botany, 41: 647-654.

Álvarez-Iglesias, L., de la Roza-Delgado, B., Reigosa, M.J., Revilla, P., Pedrol, N. 2017. A simple, fast and accurate screening method to estimate maize (Zea mays L.) tolerance to drought at early stages. Maydica, 62: 3-24.

Avramova. V., Abd Elgawad, H., Zhang, Z., Fotschki, B., Casadevall, R., Vergauwen, L., Knapen, D., Taleisnik, E., Guisez, Y., Asard, H., Beemster, G.T.S. 2015. Drought Induces Distinct Growth Response, Protection and Recovery Mechanisms in the Maize Leaf Growth Zone. Plant Phyiology, 169: 1382-1396.

Ayalew, H., Ma, X., Yan, G. 2014. Screening Wheat (Triticum spp.) Genotypes for Root Length under Contrasting Water Regmies: Potential Sources of Variability for Drought Resistance Breeding. Journal of Agronomy and Crop Science, 201(3): 189-194.

Blum, A. 2011. Drought resistance - is it really a complex trait?. Functional Plant Biology, 38: 753-757.

Comas, L., Becker, S., Cruz, V.M.Z., Byrne P.F., Dierig, D.A. 2013. Root Traits Contributing To Plant Productivity under Drought. Frontiers in Plant Science, 4.

Dhanda, S.S., Sethi, G.S., Behl, B.K. 2004. Indices of drought tolerance in wheat genotypes at early stages of plant growth. Journal of Agronomy and Crop Science, 190: 6-12.

Edmeades, G.O., Bänziger, M., Campos, H., Schussler, J. 2006. Improving tolerance to abiotic stresses in staple crops: a random or planned process. Plant Breeding: The Arnel R. Hallauer International Symposium, pp. 293-309.

Farooq, J., Khaliq, I., Ali, M.A., Kashif, M., Rehman, A.,Naveed, M., Ali, Q., Nazeer, W., Farooq, A. 2011. Inheritance pattern of yield attributes in spring wheat at grain filling under different temperature regimes. Australian Journal of Crop Science, 5(13): 1745-1753.

Guoxiong, C., Krugman, T., Fahima, T., Korol, A.B., Nevo, E. 2002. Comparative study on morphological and physiological traits related to drought resistance between xeric and mesic Hordeum spontaneum lines in Isreal. Barley Genetics Newsletter, 32: 22-33.

Hanan, E.D. 2007. Influence of salicylic acid on stress tolerance during seed germination of Triticum aestivum

and Hordeum vulgare. Advances in Biological Research, 1: 40-48.

Huang, Q., Zhao, Y., Liu, C., Zou, X., Cheng, Y. Fu, G., Xu, J., Zhang, X., Lu, G. 2015. Evaluation of and selection criteria for drought resistance in Chinese semi-winter rapeseed varieties at different developmental stages. Plant Breeding, 134(5): 542-550.

ISTA (International Seed Testing Association). 1996. International rules for seed testing rules. Seed Science and Technology. 24, Supplement.155-202.

Kauser, R., Athar, H.U.R., Ashraf, N. 2006. Chlorophyll flurescence: A potential indicator for rapid assessment of water stress tolerance in canola (Brassica napus L.). Pakistan Journal of Botany, 38: 15011509.

Khan, N.H., Ahsan, M., Naveed, M., Sadaqat, H.A., Javed, I. 2016. Genetics of drought tolerance at seedling and maturity stages in Zea maysL.. Span Journal of Agricultural Research, 14(3): e0705. http://dx.doi.org/10.5424/sjar/20161438505.

Khayatnezhad, M., Gholamin, R., Jamaati-eSomarin, S.H., Zabihi-Mahmoodabad, R. 2010. Effects of peg stress on corn cultivars (Zea mays L.) at germination stage. World Applied Sciences Journal, 11(5): 504-506.

Khodarahmpour, Z. 2011. Effect of drought stress induced by polyethylene glycol (PEG) on germination indices in corn (Zea mays L.) hybrids. African Journal of Biotechnology, 10(79): 18222-18227.

Kulkarni, M., Deshpande, U. 2007. In Vitro screening of tomato genotypes for drought resistance using polyethylene glycol. African Journal of Biotechnology, 6 : 691-696.

Kumar, A.P., Reddy, N.N., Lakshmi, J.N. 2017. PEG Induced screening for drought tolerance in tomato genotypes. International Journal of Current Microbiology and Applied Sciences, 6(7): 168-181.

Langridge, P., Reynolds, M.P. 2015. Genomic tools to assist breeding for drought tolerance. Current Opinion in Biotechnology, 32: 130-135.

Lobell, D.B., Roberts, M.J., Schlenker, W., Braun, N., Little, B.B., Rejesus, R.M., Hammer, G.L. 2014. Greater sensitivity to drought accompanies maize yield increase in the U.S. Midwest. Science, 344: 516-519. 
MoAD. 2013. Statistical Information on Nepalese Agriculture, 2012/13. Ministry of Agricultural Development, Singh Durbar, Kathmandu, Nepal.

Mostafavi, K.H., SadeghiGeive, H., Dadresan, M., Zarabi, M. 2011. Effects of drought stress on germination indices of corn hybrids (Zea mays L.). International Journal of Agricultural Science, 1(2): 10-18.

Mut, Z., Akay, H., Aydin, N. 2010. Effects of seed size and drought stress on germination and seedling growth of some oat genotypes (Avena sativa L.). African Journal of Agricultural Research, 5: 11011107.

Obidiegwu, J.E., Bryan, G.J., Jones, H.G., Prashar, A. 2015. Coping with Drought: Stress and Adaptive Responses in Potato and Perspectives for Improvement. Frontiers in Plant Science, 6.

Partheeban, C., Chandrasekhar, C.N., Jeyakumar, P., Ravikesavan, R., Gnanam, R. 2017. Effect of PEG induced drought stress on seed germination and seedling characters of maize (Zea mays L.) genotypes. International Journal of Current Microbiology and Applied Sciences, 6(5): 1095-1104.

Petcu, E., Martura, T., Ciocazanu, I., Iordan, H.L., Badut, C., Urechean, V. 2018. The Effect of water stress induced with PEG solution on maize seedlings. Romanian Agricultural Research, No. 35, DOI: 2067-5720 rar 2018-121.

Queiroz,M.S., Oliveira,C.E.S., Steiner, F., Zuffo, A.M., Zoz, T., Vendruscolo, E.P., Silva, M.V., Mello, B.F.F.R., Cabra, R.C., Menis, F.T. 2019. Drought stresses on seed germination and early growth of maize and sorghum. Journal of Agricultural Science, 11(2): 310-318.

Ribaut, J.M., Betran, J., Monneveux, P., Setter, T. 2009. Drought Tolerance in Maize. In: Bennetzen, J. \& Hake S. (Eds.) Handbook of Maize: It's Biology., pp. 311-344. Springer, New York.

Scott, S.J., Jones, R.A., Williams, W.A. 1984. Review of data analysis methods for seed germination. Crop Science, 24: 1192-1199.

Shamim, F., Saqlan, S.M., Athar, H-u-R., Waheed, A. 2014. Screening and selection of tomato genotypes/cultivars for drought tolerance using multivariate analysis. Pakistan Journal of Botany, 46: 1165-1178.

Shatpathy, P., Kar, M., Dwibedi, S.K., Dash, A. 2018. Seed priming with salicylic acid improves germination and seedling growth of rice (Oryza sativa L.) under PEG-
6000 induced water stress. International Journal of Current Microbiology and Applied Sciences, 7(10): 907-924.

Singh, B., Usha, K. 2003. Salicylic acid induced physiological and biochemical changes in wheat seedlings under water stress. Plant Growth Regulator, 39: 137-141.

Spielmeyer, W., Hyles, J., Joaquim, P., Azanza, F., Bonnet, D., Ellis, M.E., Moore, C., Richards, R.A. 2007. A QTL on chromosome $6 A$ in bread wheat is associated with longer coleoptiles, greater seedling vigor and final plant height. Theoretical and Applied Genetics, 115: 59-66.

Steel, R.G.D., Torrie, J.H., Dickey, D.A. 1997. Principles and Procedures of Statistics; A Biometrical Approach. 3. Boston: McGraw-Hill.

Tripathi, M.P., 2012. Development of Drought and Low N Stress Tolerant Maize Cultivars for Terai and Mid hills of Nepal. Annual Report of National Maize Research Program 2011/12, Rampur, Chitwan, Nepal, pp. 103-107.

Tsago, Y., Andargie, M., Takele, A. 2014. In vitro selection of sorghum (Sorghum bicolor (L.) Moench) for polyethylene glycol (PEG) induced drought stress. Plant Science Today, 1(2): 62-68.

Zhan, A., Schneider, H., Lynch, J.P. 2015. Reduced Lateral Root Branching Density Improves Drought Tolerance in Maize. Plant Physiology, 16. 